\title{
CHARACTERISTICS OF THE SURROUNDING AREAS OF BRT STATIONS IN JAMBI PROVINCE BASED ON LAND-USE DIVERSITY
}

\author{
Nindya Kusumaputri Suwarto ${ }^{1 *}$, Bambang Hari Wibisono² \\ ${ }^{1}$ Department of Architecture and Planning, Faculty of Engineering, Universitas Gadjah Mada, Yogyakarta, Indonesia \\ ${ }^{2}$ Department of Architecture and Planning, Faculty of Engineering, Universitas Gadjah Mada, Yogyakarta, Indonesia
}

Jambi Provincial Government tries to overcome congestion by providing public transportation, Bus Rapid Transit (BRT) system, known as BRT Trans Siginjai Jambi. Public transportation Trans Siginjai Jambi has been operating for two years and has 11 BRT Stations. Placement of the transit node is one of the determinants of the role of bus stations in the surrounding area. The diversity of land-use and facilities close to the transit area can reduce travel time, so it is necessary to map the land-use that will determine the physical characteristics of the area around the BRT Station. This study discusses the characteristics of the area around the BRT Station using quantitative methods. Quantitative methods are used to determine the characteristics of BRT Station based on the variables of the proportion of land use in the area around the BRT Station. The land-use variable is obtained from the Transit-Oriented Development (TOD) theory. The study produced three characteristics of BRT Station, namely City Station, Neighborhood Station, and Special Activity Station.
\end{abstract}

ARTICLE INFO

\section{Keywords:}

Bus Rapid Transit, Land-use, Jambi, TOD, Characteristics, BRT Station

\section{Introduction}

Law of the Republic of Indonesia No. 26 Year 2007 (UU RI No. 26 Tahun 2007) regarding Spatial Planning explained that urban areas are areas that have the main activities not agriculture, with the arrangement of the function of the area as a place for urban settlements, centralization and distribution of government services, social services, and economic activities (Undang-Undang Republik Indonesia Nomor 26 Tahun 2007 tentang Penataan Ruang, 2007). In the Habitat III conference held by UN-Habitat (PBB) in Quito, Ecuador on October 20, 2016 produced a new idea for cities and settlements in the world, the New Urban Agenda (NUA). In the NUA guidelines issued by the UN, it is explained that in 2050, the number of urban population in the world is projected to double. This condition is predicted to continue until 2035, which is projected that around $67 \%$ of Indonesia's population will live in cities (Ministry of Public Works and Public Housing of Republic Indonesia, 2017). With these assumptions, planning for a city is crucial. Uncontrolled urban development has an impact to the development of problems that occur therein, like social and environmental problems in society, garbage, air pollution, floods, congestion, and crime. Congestion is an impact that occurs from increasing mobility in the city that is not controlled as the population is increasing.
Cities that have not yet implemented a mass public transportation system have an impact on the high congestion rate, especially on the use of private vehicles. Providing mass transportation does not need to wait for a city to become metropolitan or have more than 2-3 million people. Cities with populations above 500.000 can immediately implement mass transportation (ITDP Indonesia, 2018). This strategy minimizes congestion problems in the city early on. Prof. Robert Cevero from the University of California Berkeley, United States, recommends that cities which have not been able to make a rail-based transportation system (Subway) such as in Indonesia, begin to develop a bus-based transportation system (BRT). Robert also explained that the big cities of Indonesia must begin to review the conditions of transportation and land-use in order to achieve a humanistic urban planning (Ministry of Transportation Republic of Indonesia, 2012). The Bus Rapid Transit (BRT) system was first implemented in Jakarta, Indonesia in 2004, known as Transjakarta and became the first in Southeast and South Asia at that time. Transjakarta is mass transportation that is designed to reduce congestion in the capital city (Transjakarta.co.id., 2016).

Based on Central Bureau of Statistics data from Jambi Province in 2018, the number of residents in Jambi City in 
the last five years has increased (Central Bureau of Statistics of Jambi City, 2018). The increasing population is accompanied by an increase in the number of private vehicle users which has an impact on the increasing point of congestion in the Jambi City. The growth rate of motor vehicles has reached $5 \%$ in the last five years with a percentage of the number of motorbikes at $87,18 \%$ of the total number of motor vehicles for the period of 20102014. The ratio of the number of motorcycles and population in the city of Jambi reached 1:10 at the end of 2014 (Mangatur et al., 2018). Until the end of 2015, the efforts made by the local government in dealing with congestion problems focused on improving road infrastructure such as, road widening and addition of road networks, road engineering, and restrictions on the purchase of private vehicles (Jambi Ekspres, 2015).

At the end of 2017, the Jambi provincial government began testing The Bus Rapid Transit (BRT) system, known as Trans Siginjai, as an effort to unravel urban congestion. Trans Siginjai officially operates in March 2018 with the first route/corridor 1 starting from the Governor's office area in Telanaipura, Jambi City to Pijoan, Muaro Jambi Regency. Corridor 1 is $19 \mathrm{~km}$ which is served by 19 BRT Stations, 7 permanent stops, and 12 portable stops (Pramono, 2017). The BRT Stations are located at 11 points. One BRT Station serves an area with a diverse radius ranging from $1 \mathrm{~km}$ to $4 \mathrm{~km}$. At the same time, walking distance in the Indonesian context is $400 \mathrm{~m}$ or $300 \mathrm{~m}$ if carrying loads (Indraswara, 2007).

Evaluation of the BRT Trans Siginjai service route was discussed in research on "Spatial Patterns for using Private Vehicles to Evaluate Routes of Bus Rapid Transit in Jambi Province" by Thias Adiyasa in 2019. The study explained the evaluation of the BRT Station point in the BRT Trans Siginjai corridor 1 to the suitability of the movement of community activities in the area around the transit node. The results of the study stated that the BRT Trans Siginjai corridor 1 service route has accommodated potential movement patterns, although not all have been served (Adiyasa, 2019). Characteristics of BRT Stations have not been discussed in Adiyasa's research. Characteristics of BRT Stations can be used as guidelines for the development of the area around the BRT Station in the future. The purpose of this study was to determine the characteristics of the area around the BRT Station of Trans Siginjai based on the diversity of land use. For that purpose, it is necessary to identify land use in the area around the BRT Station, which is then grouped according to the proportion of building functions.

\section{Literature Review}

A literature study is used in research based on the topic of developing BRT-based transit areas. This study uses the Transit-Oriented Development (TOD) theory and the landuse theory related to the diversity of land-use. TOD theory is used to find out more deeply about the typology of transit-based areas. Land-use theory is used as a basis for determining building functions in the area around the BRT Stations.

Transit-Oriented Development Area hereinafter referred to as TOD is the concept of developing areas in and around the transit node in order to have the high value that focuses on the integration between mass public transportation networks, and between mass public transportation networks and non-motorized modes of transportation, and reduction in the use of motor vehicles accompanied by the development of mixed and dense areas with moderate to high intensity of space utilization (Regulations of Ministry of Agrarian Affairs and Spatial Planning Republic of Indonesia No.16, 2017). In the TOD principle, mixed landuse consists of three functions, namely residential, public facilities, and commercial/offices in the core area (Calthorpe, 1993). In general, land-use is an effort for planning the land functions in an area by dividing the area into certain functions, such as commercial or trade functions, settlements, industrial zones, government areas, and recreational areas (Arifia, 2014). In some TOD theories, land-use is one of the main factors that determine land functions in the area around the transit point. Variety of land functions in the 5D of TOD principle (Density, Diversity, Design for Walkability, Distance to transit, and Destination Accessibility) are included in Diversity (Widyastuti, 2017).

The diversity of land functions is used to determine the TOD characteristics of each transit node in an area. The transit area in the corridor 1 of Jambi Province is a busbased transit area, so the TOD character is used as a character for the transit area around the BRT Station Trans Siginjai. TOD theories used in this study as a basis for determining transit node characters are The Next American Metropolis by Peter Calthorpe in 1993, Transit-Oriented Development: Guide for Practitioners in Queensland in 2010, Florida TOD Guidebook in 2012, TOD Guidelines for the City of Edmonton, and Regulation of the Minister of Agrarian Affairs and Spatial Planning No.16 of 2017 concerning Guidelines for Development of TransitOriented Areas.

Table 1. Characteristics of the Area Around the Transit Node Based on a Literature Study

\begin{tabular}{|c|c|c|c|c|c|}
\hline \multirow[b]{2}{*}{ BRT Station Type } & \multicolumn{5}{|c|}{ TOD Theory Related to the Characteristics of the TOD Area } \\
\hline & $\begin{array}{c}\text { Peter Calthorpe, } \\
1993\end{array}$ & $\begin{array}{l}\text { TOD Guide of } \\
\text { Queensland, } \\
\text { Queensland } \\
\text { Government, } \\
2010\end{array}$ & $\begin{array}{c}\text { Florida TOD } \\
\text { Guidebook (Florida } \\
\text { Department of } \\
\text { Transportation), } \\
2012\end{array}$ & $\begin{array}{l}\text { TOD Guidelines the City } \\
\text { of Edmonton, } 2012\end{array}$ & $\begin{array}{c}\text { Regulations of } \\
\text { Ministry of } \\
\text { Agrarian Affairs } \\
\text { and Spatial } \\
\text { Planning No.16, } \\
2017 \\
\end{array}$ \\
\hline City Station & Urban TOD & $\begin{array}{l}\text { City Centre } \\
\text { Urban }\end{array}$ & Regional Center & Downtown & City TOD \\
\hline Sub-Urban Station & & Suburban & & & Sub-Urban TOD \\
\hline $\begin{array}{l}\text { Neighborhood } \\
\text { Station }\end{array}$ & $\begin{array}{l}\text { Neighborhood } \\
\text { TOD }\end{array}$ & Neighborhood & Neighborhood Center & $\begin{array}{c}\text { Neighborhood } \\
\text { New Neighborhood } \\
\text { Enhanced Neighborhood }\end{array}$ & Neighborhood TOD \\
\hline
\end{tabular}


Peter Calthorpe explained that the TOD area has 2 criteria, Urban TOD and Neighborhood TOD. The function in the TOD area consists of the residential function, commercial/office function, and public facility function (Calthorpe, 1993). TOD Queensland has 6 TOD criteria, city centre, activity centre, specialist activity centre, urban, and suburban (Queensland Government, 2010). The functions of TOD are residential, commercial, retail, and community. TOD Florida has 3 TOD typologies, consist of regional center, community center, and neighborhood center. The functions of the area are divided into residential and nonresidential (Busha et al., 2012). TOD guideline the city of Edmonton has 7 types of station areas namely, neighborhood, new neighborhood, enhanced neighborhood, centre, employment, institution/recreation, and downtown (City of Edmonton, 2012). TOD city of Edmonton has no special grouping in the diversity of land functions. Type of TOD issued by Minister of Agrarian and Spatial Planning Regulation 16 of 2017 concerning Guidelines for Development of Transit-Oriented Areas has 3 typologies of TOD, namely City TOD - City Service Center, Sub City TOD - Sub City Service Center, and Neighborhood TOD - Service Center Environment. Types of spatial use in the TOD area consist of housing and non-housing ((Regulations of Ministry of Agrarian and Spatial Planning Republic of Indonesia No.16, 2017).

TOD type issued by Indonesia government, The Ministry of Agrarian and Spatial Planning is assumed to be the closest type and suitable to the condition of the Indonesian Region. City TOD is the economic centre and regional culture. Sub-City TOD is the secondary economic centre. Neighborhood TOD consists of the local economic centre and local community, and also dominated by households with good access to the regional or subregional area.

Each of TOD Region has a different type of TOD typology. From the service coverage of the TOD Region and the diversity of spatial functions, there are some similarities from the TOD typologies. The typologies that have the same range of services and diversity of facilities can be grouped into one TOD Zone category. Based on the description of each TOD's scope typology, the transit node of the BRT Station Trans Siginjai Jambi can be grouped into 3 characteristics of the TOD Area, namely City Station, Suburban Station, and Neighborhood Station. This category corresponds to Ministerial Regulation of Agrarian and Spatial Planning No 16 of 2017. Table 1 describes the characteristics of BRT Station based on the typology of each TOD area.

\section{Research Method}

This study uses a quantitative approach by assessing the proportion of diversity in land use. The first step is to identify building functions in the area around the transit node. The next step is to do the assessment of the percentage of land use and see the proportion to determine the characteristics of BRT station in the area. The characteristics category of BRT station is divided into 3, city station, suburban station, and neighborhood station. Table 2 explains the research variable that consists of the percentage of land use diversity for each characteristic of BRT Station. The land functions are grouped into 3 functions, namely residential, commercial/office, and public facilities.

Table 2. Land-Use Variables

\begin{tabular}{lccc}
\hline \multicolumn{1}{c}{ Parameter } & \multicolumn{3}{c}{ Indicators } \\
\cline { 2 - 4 } & City & Sub-Urban & Neighborhood \\
\hline Residential & $20-60 \%$ & $30-60 \%$ & $60-80 \%$ \\
\hline $\begin{array}{l}\text { Commercial/ } \\
\text { Office }\end{array}$ & $30-70 \%$ & $30-50 \%$ & $10-30 \%$ \\
\hline Public Facilities & $5 \%$ & $10 \%$ & $15 \%$ \\
\hline
\end{tabular}

The residential function is a household area. Commercial or office functions are the trade areas of goods and services, retail and offices for the private and public sectors. The function of public facilities consists of buildings that have services for the community, such as education buildings, campuses or schools, hospitals, city parks, and worship buildings.

The research location is in the province of Jambi in the corridor I BRT Trans Siginjai. The length of the corridor 1 reaches $19 \mathrm{~km}$ which is in 2 regions within the province, namely Jambi City and Muaro Jambi Regency. Figure 1 shows a map of Jambi Province and the location of Jambi City and Muaro Jambi Regency.

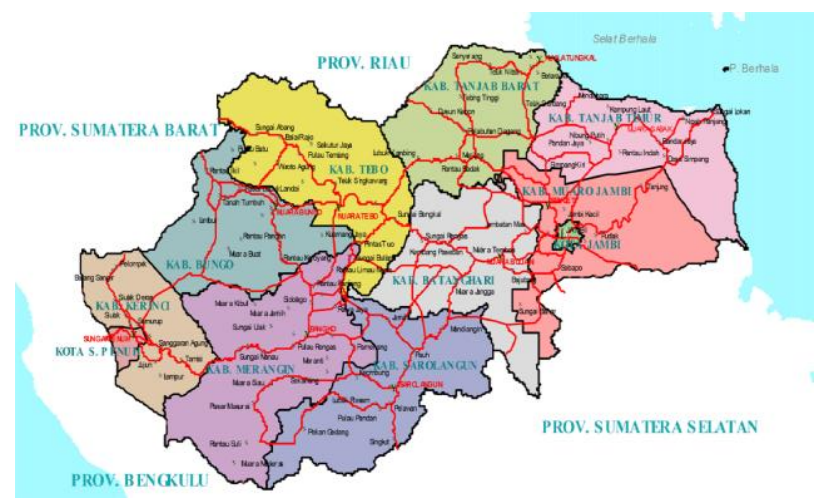

Figure 1. Map of the Administration of the Province of Jambi

Source: Central Bureau of Statistics of Jambi Province (2020)

The route of corridor planning consists of 4 routes $1 \mathrm{BRT}$ Trans Siginjai Jambi has 11 BRT Stations. Figure 2 shows the 4 corridors that will be provided by Department of Transportation of Jambi Province. Nowadays, there are only 2 corridors that actively operated, corridor 1 and corridor 2. Corridor 2 is in the experimental stage and corridor 1 is fully operated. Corridor 1 with the red line serves the routes Bapelkes Pijoan - Angso Duo Traditional Market - The Sijenjang Terminal. Corridor 2 serves the routes Regent's office of Muara Jambi (Sengeti) - Jambi Market Centre Airport. Corridor 3 serves the routes Tempino - Paal Merah Lama. Corridor 4 serves the routes The Alam Barajo Terminal - Lingkar Barat - Lingkar Selatan - Lingkar Timur - The Sijenjang Terminal - Muaro Jambi Temple. 


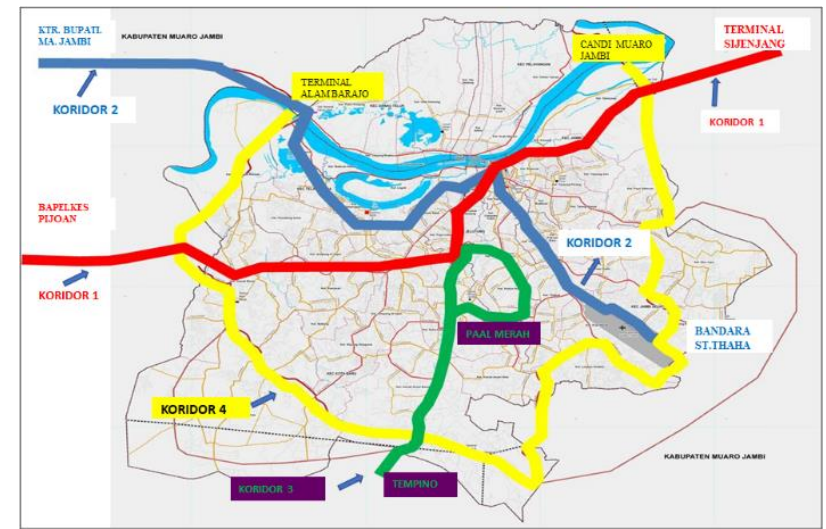

Figure 2. Corridor Routes of BRT Trans Siginjai Jambi

Source: Department of Transportation of Jambi Province (2019)

Figure 3 shows the location of 11 BRT Stations located along the corridor. The observation area is at a radius of $400 \mathrm{~m}$ from the BRT Station according to the distance of pedestrians in Indonesia (Indraswara, 2007).

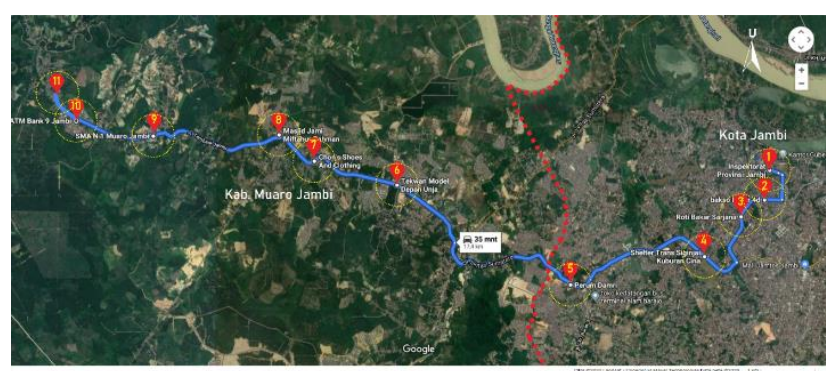

Figure 3. The Distribution of Bus Station in Corridor I Source: Google Satellite Image (2019)

Table 3 shows the location of the BRT Station in corridor 1. Bus Station 01 Inspektorat to Bus Station 05 Simpang Rimbo is in the Jambi City area, while Bus Station 6 from UNJA Mendalo to Bus Station 11 Balpelkes Pijoan is in the Muaro Jambi Regency.

Table 3. The Location of BRT Station Trans Siginjai in Corridor 1

\begin{tabular}{ll}
\hline \multicolumn{1}{c}{ BRT Station Name } & \multicolumn{1}{c}{ Location } \\
\hline Bus Station 01 Inspektorat & Kel. Telanaipura, Kec. \\
& Telanaipura, Kota Jambi \\
\hline Bus Station 02 UNJA Telanai & Kel. Telanaipura, Kec. \\
& Telanaipura, Kota Jambi \\
\hline Bus Station 03 UIN Telanai & Kel. Simpang IV Sipin, Kec. \\
& Telanaipura, Kota Jambi \\
\hline Bus Station 04 LP Jambi & Kel. Simpang IV Sipin, Kec. \\
& Telanaipura, Kota Jambi \\
\hline Bus Station 05 Simpang Rimbo & $\begin{array}{l}\text { Kel. Kenali Besar, Kec. Kota } \\
\text { Baru, Kota Jambi }\end{array}$ \\
\hline Bus Station 06_UNJA Mendalo & $\begin{array}{l}\text { Kel. Mendalo Darat, Kec. Jambi } \\
\text { Luar Kota, Kab. Muaro Jambi }\end{array}$ \\
\hline Bus Station 07 UIN Mendalo & $\begin{array}{l}\text { Kel. Simpang Sungai Duren, } \\
\text { Kec. Jambi Luar Kota, Kab. } \\
\text { Muaro Jambi }\end{array}$ \\
\hline Bus Station 08 Simpang Sungai & $\begin{array}{l}\text { Kel. Simpang Sungai Duren, } \\
\text { Duren }\end{array}$ \\
Kec. Jambi Luar Kota, Kab. \\
Muaro Jambi \\
\hline Bus Station 09 SMA N 01 Ma. & $\begin{array}{l}\text { Pijoan, Kec. Jambi Luar Kota, } \\
\text { Kab. Muaro Jambi }\end{array}$ \\
\hline Jambi & $\begin{array}{l}\text { Pijoan, Kec. Jambi Luar Kota, } \\
\text { Bus Station 10 SMA TT }\end{array}$ \\
\hline Bus Station 11 Balpelkes Pijoan & $\begin{array}{l}\text { Pijoan, Kec. Jambi Luar Kota, } \\
\text { Kab. Jambi }\end{array}$ \\
\hline &
\end{tabular}

\section{Results and Discussions}

The results of the study were in the form of grouping characteristics of BRT Stations. The grouping is based on identifying patterns of diversity in the land function around the BRT Station of Trans Siginjai in Jambi Province. Table 4 shows the proportion of diversity of land functions from each region around the transit node.

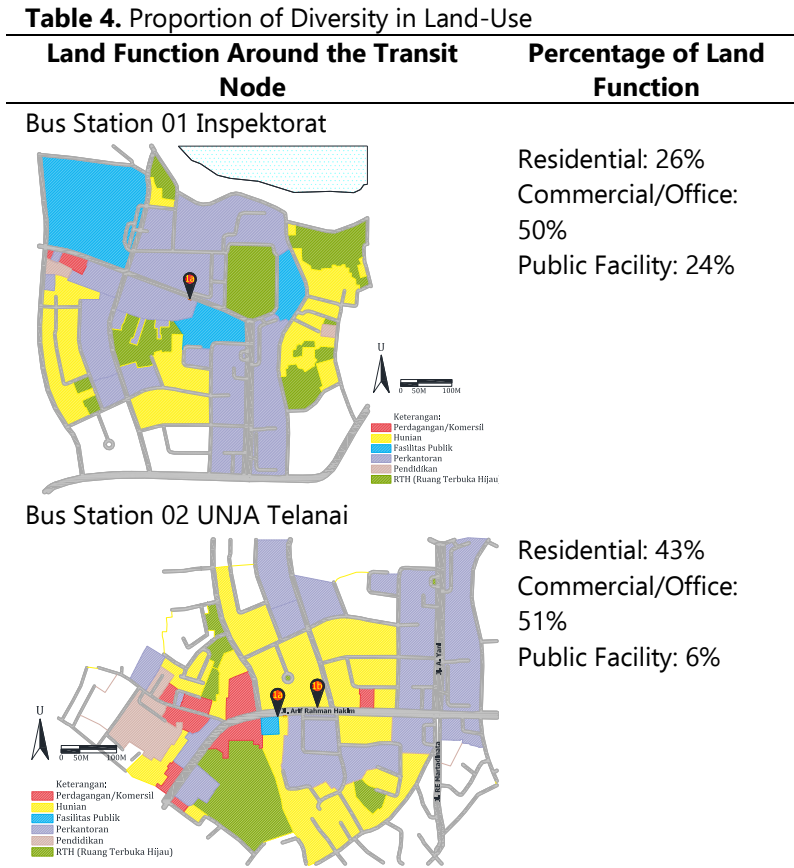

Bus Station 03 UIN Telanai

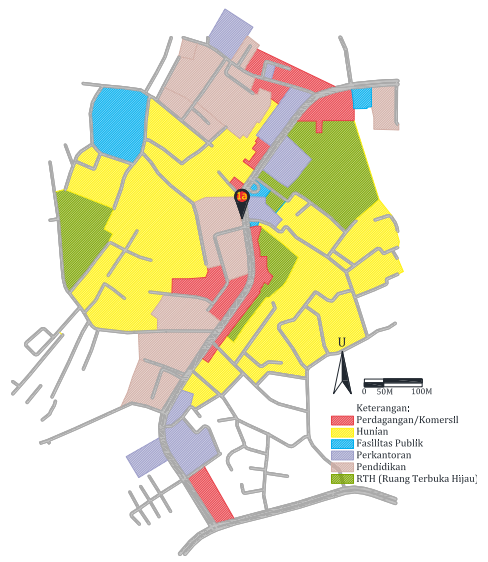

Residential: $53 \%$ Commercial/Office: 19\%

Public Facility: 28\%

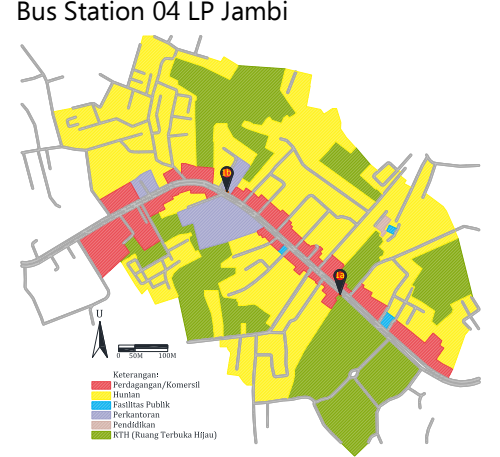

Residential: $78 \%$ Commercial/Office: $21 \%$ Public Facility: 1\% 
Bus Station 05 Simpang Rimbo

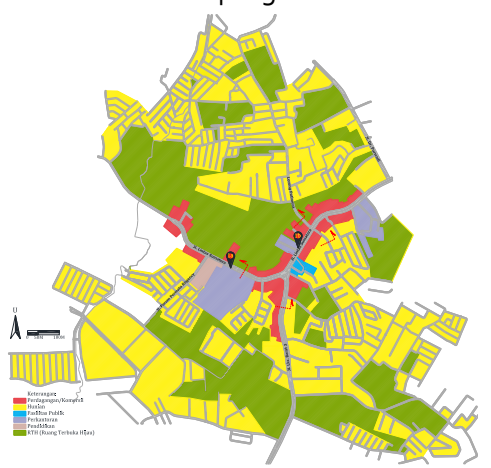

Bus Station 06 UNJA Mendalo

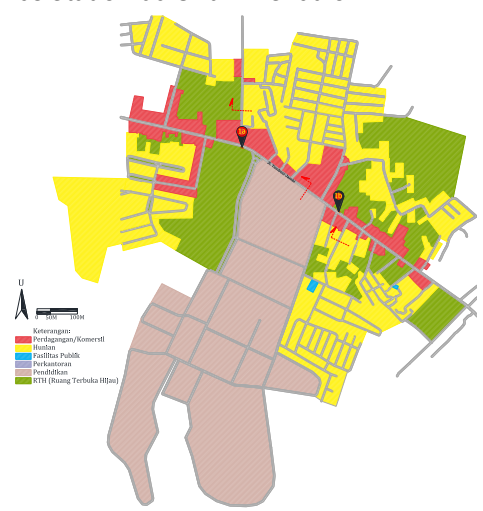

Bus Station 07 UIN Mendalo

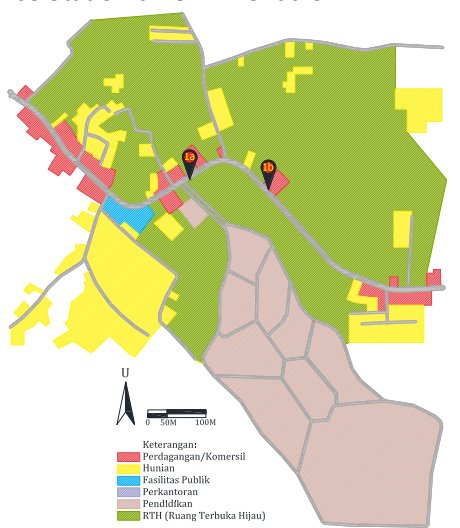

Bus Station 08 Simp Sungai Duren

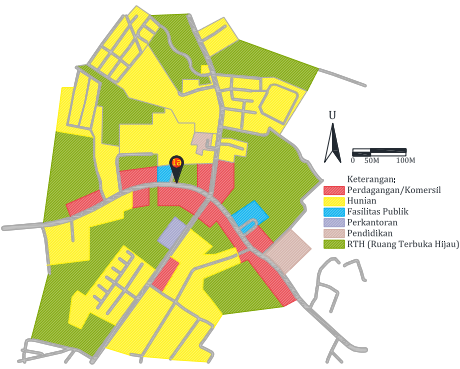

Bus Station 09 SMA N 1 Ma. Jambi

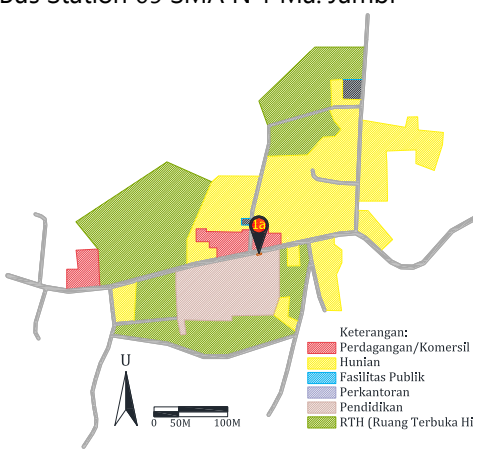

Residential: $86 \%$ Commercial/Office: $13 \%$

Public Facility: $1 \%$

Residential: $46 \%$

Commercial/Office: $10 \%$

Public Facility: $44 \%$

Residential: $35 \%$ Commercial/Office: $9 \%$

Public Facility: 56\%

Residential: $77 \%$

Commercial/Office: $16 \%$

Public Facility: $7 \%$

Residential: $70 \%$ Commercial/Office: $8 \%$

Public Facility: 22\%

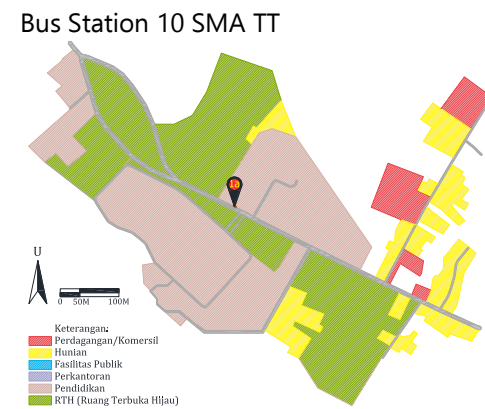

Residential: $24 \%$

Commercial/Office:

9\%

Public Facility: 67\%

Bus Station 11 Bapelkes Pijoan

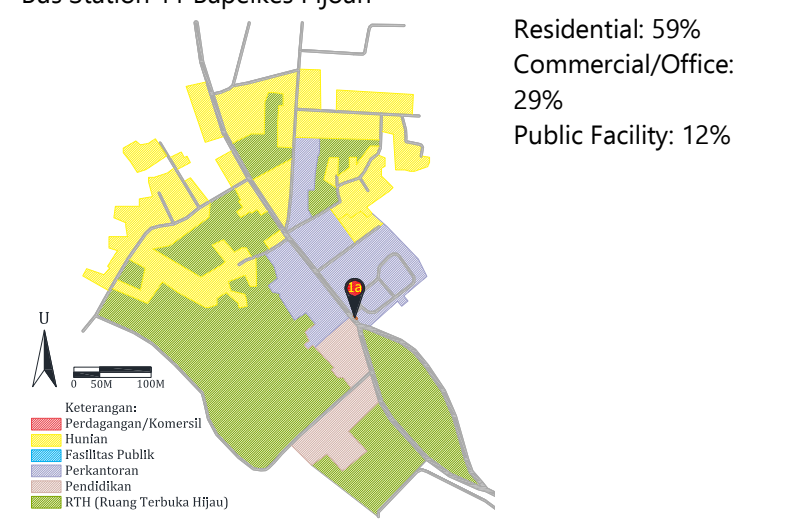

Bus Station 01 Inspektorat is in the Provincial Government office area. The function of land at a radius of $400 \mathrm{~m}$ from the Bus Station 01 has 6 different functions, namely, commercial/office functions, residences, public facilities, offices, education, and green open space. The percentage of land function based on land-use variables shows that the Bus Station area is dominated by commercial/office areas by $50 \%$, residential area reaches $26 \%$, and public facilities reach $24 \%$. The office function has the largest area because the BRT Station is located in the provincial government office area. Based on the percentage value, Bus Station 01 Inspektorat can be categorized into a City Station.

Bus Station 02 UNJA Telanai is located on the campus and office area. The diversity of land functions consists of commercial, housing, public facilities, offices, education, and green open space. The percentage of land functions was dominated by office functions by $51 \%$ consisting of government offices and the UNJA Telanai campus. The campus of UNJA Telanai has functioned as a service office and non-regular program. The residential area reaches $43 \%$. The function of public facilities is $6 \%$ consisting of worship and Education facilities. From the results of this percentage, the characteristics of Bus Station 02 is City Station.

Bus Station 03 UIN Telanai is located in a densely populated area and public facilities such as education buildings. Residential function dominates the area by $53 \%$. The commercial and office functions reach $19 \%$. The function of public facilities at $28 \%$ consists of sports and worship facilities at $5 \%$, and education facilities at $23 \%$. Educational facilities at the UIN Telanai campus are dominated by student service offices, while lecture activities are on the UIN Mendalo campus. Based on this percentage, Bus Station 03 approaches the characteristics of the Neighborhood Station. 
Bus Station 04 LP and Bus Station 05 Simpang Rimbo are located in residential areas. Based on the percentage of land use diversity, both BRT Stations have the same percentage of land-use and proper as the characteristics of the Neighborhood Station. Bus Station 04 has a percentage of residential function reaching $78 \%$, commercial and office functions $21 \%$, and public facilities function of $1 \%$. While Bus Station 05 has a percentage of residential reaching $86 \%$, commercial and office functions $13 \%$, and public facilities function of $1 \%$. The two BRT Stations have the same spatial structure pattern, which is the location of the commercial and office functions are along the arterial road. Public facilities at $1 \%$ are religious facilities.

Bus Station 08 Simpang Sungai Duren, Bus Station 09 SMA N 01 Ma. Jambi, and Bus Station 11 of the Bapelkes Pijoan are included in the characteristics of the Neighborhood Station. All three stops have similar proportions. Bus Station 08 Simpang Sungai Duren is located in the Jambi Sub-district of the city, Muaro Jambi Regency. Based on an interview with the Jambi Provincial Transportation Department, Endy Syafeti, S.SIT., M.T., the Land and Rail Transportation Section of the BRT Trans Siginjai user in the Muaro Jambi Regency is used more by employees who work in Jambi City but live in the regency. The composition of land functions around the area of Bus Station 08 consists of commercial, office, public facilities, residential, education, and green space functions. The function of the area is dominated by residential, green open space, and vacant land that is still in the process of development. The percentage of occupancy function reaches $77 \%$, commercial and office functions reach $16 \%$, and public facilities function reaches $7 \%$. Public facilities consist of religious facilities and gas stations by $2 \%$ and educational facilities by $5 \%$.

Bus Station 09 SMA N 01 Ma. Jambi is located in Pijoan, Jambi Luar Kota District, Muaro Jambi Regency. The composition of land functions around the BRT Station consists of commercial functions, public facilities, housing, education, and green open space. The function of the area is dominated by undeveloped residential and green land. The residential function reaches $70 \%$, the commercial function reaches $8 \%$, and public facilities which are consisted of $1,5 \%$ worship function and $20,5 \%$ educational function with a total of $22 \%$.

Bus Station 11 Bapelkes is located in Pijoan, Jambi Luar kota, Muaro Jambi Regency. The composition of land functions around the Bus Station consists of office, housing, education, and green open space functions. The function of the area is dominated by undeveloped green land. Based on the diversity of land functions at Station 11, the percentage of residential functions reaches $59 \%$, office functions $29 \%$, and public facilities which consist of educational facilities reach $12 \%$.

Bus Station 06 UNJA Mendalo, Bus Station 07 UIN Mendalo, and Bus Station 10 SMA TT have the same character with the highest percentage of public facility functions, more than $40 \%$. Bus Station 06 is located in the UNJA Mendalo campus area. The proportion of the diversity of functions at Bus Station 06 consists of a residential function of $46 \%$, the function of public facilities consisting of educational facilities amounting to $43,9 \%$, and worship facilities only reaching $0,1 \%$ with a total of $44 \%$, and trading functions reaching $10 \%$. The Jambi Provincial Transportation Department, the Land and Railroad Sector, Endy Syafeti, S.SIT., M.T., explained that the existence of Bus Station 06 aims to support campus functions located outside the Jambi City, making it easier for students residing in the City Center.

Bus Station 07 UIN Mendalo is similar to Bus Station 06, located in the UIN Mendalo campus area. Bus Station 07 has a proportion of diversity of functions consisting of 35\% occupancy function and $9 \%$ commercial function. The function of public facilities consists of educational facilities by $55 \%$ and worship and health facilities only reach $1 \%$ with a total of $56 \%$. The UIN Mendalo campus is the main function in the region, which dominates half of the area.

Bus Station 10 SMA TT is located at Jalan Lintas Sumatera KM 21, Pijoan, Jambi Luar Kota, Muaro Jambi Regency. The occupancy function reaches $24 \%$ and trade reaches $9 \%$. Public facilities are educational facilities that reach $67 \%$. Educational facilities available are Titian Teras High School (TT), MAN Insan Cendekia Jambi, and Elementary School 02 Pijoan.

Based on the observations to the proportion of land functions at Bus Station 06, Bus Station 07, and Bus Station 10 , the three BRT Stations are not appropriate if they are categorized into 3 Characteristics of BRT Station in accordance with the research variables. The three BRT Stations have special functions that support the main activities in the surrounding area. The main activity is educational activities. According to TOD Queensland, in the TOD area which has a special activity center that is public institutions, such as hospitals and universities included in the TOD Specialist Activity Center category (Queensland Government, 2010). Meanwhile, according to TOD the City of Edmonton, the category of TOD area which is dominated by educational areas or campuses or recreational facilities is included in the TOD Institution/Recreation typology. The purpose of the transit node on the type of TOD Institution is to support the existence of institutional functions to facilitate the public to access the Region (City of Edmonton, 2012). Based on these 2 theories, then Bus Station 06, Bus Station 07, and Bus Station 10 can be categorized into a Special Activity Station, where the education function is the main function within the region.

The conclusions of the results are summarized in Table 4 regarding the characteristics of the 11 BRT Stations in Trans Siginjai Jambi Corridor 1. Out of a total of 11 BRT Stations, there is no BRT Station that shows the characteristics of a sub-urban station, so that the types of BRT Stations that conform to the research variables are only City Station and Neighborhood Station. In contrast, there is one type of BRT Station area that is in accordance with the conditions of the field, namely the Special Activity Station. The allotment of the City Station is in Bus Station 01 Inspektorat and Bus Station 02 UNJA Telanai. Allotment for the Neighborhood Station, located in 6 bus stops areas, namely, Bus Station 03 UIN Telanai, Bus Station 04 LP Jambi, Bus Station 05 Simpang Rimbo, Bus Station 08 Simpang Sungai Duren, Bus Station 09 SMA N 01 Ma. Jambi, and Bus Station 11 
Bapelkes Pijoan. The Special Activity Station is intended for the area of Bus Station 06 of UNJA Mendalo, Bus Station 07 of UIN Mendalo, and Bus Station 10 of SMA TT.

Table 5. Resume Characteristic of BRT Stations

\begin{tabular}{lc}
\multicolumn{1}{c}{ Station Name } & $\begin{array}{c}\text { Characteristic of BRT } \\
\text { Station }\end{array}$ \\
\hline Bus Station 01 Inspektorat & $\begin{array}{c}\text { City Station } \\
\text { City Station } \\
\text { Bus Station 02 UNJA Telanai }\end{array}$ \\
Bus Station 03 UIN Telanai & Neighborhood Station \\
Bus Station 04 LP Jambi & Neighborhood Station \\
Bus Station 05 Simpang Rimbo & Neighborhood Station \\
Bus Station 06 UNJA Mendalo & Special Activity Station \\
Bus Station 07 UIN Mendalo & Special Activity Station \\
Bus Station 08 Simpang Sungai Duren & Neighborhood Station \\
Bus Station 09 SMA N 01 Ma. Jambi & Neighborhood Station \\
Bus Station 10 SMA TT & Special Activity Station \\
Bus Station 11 Balpelkes Pijoan & Neighborhood Station \\
\hline
\end{tabular}

Figure 4 explains the distribution of BRT Station along the BRT Trans Siginjai Corridor I in Jambi. The red circle is the City Station Area with a total of 2 transit nodes. The green circle is the Neighborhood Station area with a total of 6 transit nodes. The blue circle is the Special Activity Station Area with a total of 3 transit nodes.

\section{Conclusion}

Based on the results of the discussion, this study concludes that there are 2 characteristics of BRT Stations that correspond to the research variables, namely the City Station and the Neighborhood Station. From a total of 11 BRT Stations located along Corridor 1 of Trans Siginjai Jambi, there are 2 City Stations and 6 Neighborhood Stations. The character of the region from 3 BRT Stations does not match the criteria of 3 stations typology. From the diversity of functions, these stations can be categorized as special activity station.

From the discussion, City Station has the largest percentage of office function followed by residential function. Neighborhood station has the largest residential function followed by office function. Meanwhile, the special activity station that has been found during the research focuses on public facilities as the largest percentage. The facilities dominated by education activities.

This paper discusses about characteristic of BRT station based on the diversity of land-use. Suggestion for the next research is to discuss about the density in each type of BRT station.

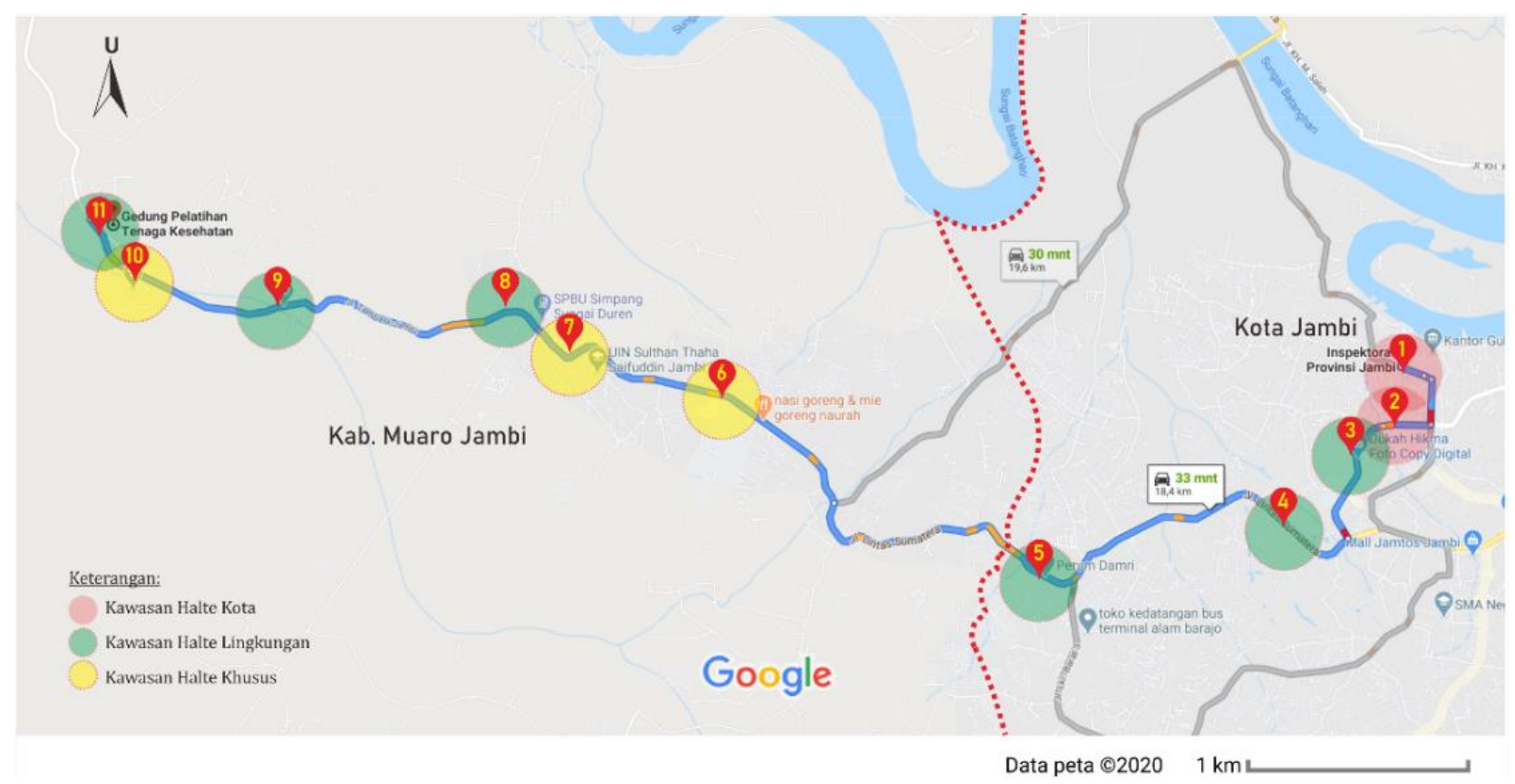

Figure 4. Distribution of Transit Nodes Based on Characteristic of BRT Station 


\section{References}

Adiyasa, M. T. (2019). Pola Spasial Penggunaan Kendaraan Pribadi untuk Mengevaluasi Rute Layanan Bus Rapid Transit di Provinsi Jambi. Jurnal Manajemen Transportasi \& Logistik, 06(01), 65-92.

Arifia, D. (2014). Teori Tata Guna Lahan (Land Use). www.academia.edu, 1-25. https://www.academia.edu/13367793/Teori_Tata_Guna_La han_Land_Use_.

BPS Kota Jambi. (2018). Statistik Daerah Kota Jambi 2018 (Badan Pusat Statistik Kota Jambi (ed.). Badan Pusat Statistik Kota Jambi. https://pontianakkota.bps.go.id/

BPS Provinsi Jambi. (2020). Provinsi Jambi Dalam Angka 2020. BPS Provinsi Jambi.

Busha, M., Brunot, M., DeLaney, K., Fett, S., Gianniotes, A., Hatton, W., Hutton, C., Little, D., \& Sabol, E. (2012). Florida TOD Guidebook. In Florida TOD Guidebook (Issue December). Florida Department of Transportation.

Calthorpe, P. (1993). The Next American Metropolis: Ecology, Community and the American Dreams. Princeton Architectural Press.

City of Edmonton. (2012). Transit Oriented Development Guidelines The City of Edmonton. Sustainable Development and Transportation Services Departments, City of Edmonton.

Dinas Perhubungan Provinsi Jambi. (2019). BRT Trans Siginjai Jambi 2019.

Dirjen Perhubungan Darat RI. (2012). Bus rapid transit ideal dikembangkan di indonesia. Direktorat Jenderal Perhubungan Darat Kementerian Perhubungan Republik Indonesia. http://hubdat.dephub.go.id/berita/1010-busrapid-transit-ideal-dikembangkan-di-indonesia

Indraswara, M. (2007). Kajian Kenyamanan Jalur Pedestrian Pada Jalan Imam Barjo Semarang. Enclosure, 6(2), 59-69.

ITDP Indonesia. (2018). Mengapa (harus) BRT? ITDP Institure for Transportation \& Development Policy. http://www.itdpindonesia.org/blog/mengapa-harus-brt/
Jambi Ekspres. (2015). Pertumbuhan Kendaraan Tak Dibarengi Pertumbuhan Jalan. JAMBIEKSPRES.CO.ID. http://www.jambiekspres.co.id/read/2017/02/12/19539/pe rtumbuhan-kendaraan-tak-dibarengi-pertumbuhan-jalan

Kementerian PUPR. (2017). Panduan Praktis Implementasi Agenda Baru Perkotaan - New Urban agenda. In Journal of Chemical Information and Modeling. https://doi.org/10.1017/CBO9781107415324.004

Mangatur, Edison, \& Suandi. (2018). Analisis Dampak Kemacetan Lalu Lintas Terhadap Pendapatan Masyarakat dan Aksesibilitas Di Kota Jambi. Jurnal Pembangunan Berkelanjutan, 1(1), 1-10.

Lampiran Peraturan Menteri Agraria dan Tata Ruang No.16 Tahun 2017 tentang Pedoman Pengembangan Kawasan Berorientasi Transit, Pub. L. No. Berita Negara Republik Indonesia Tahun 2017 Nomor 1408 (2017).

Undang-Undang Republik Indonesia Nomor 26 Tahun 2007 tentang Penataan Ruang, Pub. L. No. 26 Tahun 2007, Sekretariat Negara RI (2007). https://doi.org/10.23943/9781400889877

Pramono, Y. (2017). Bus Trans Siginjai Mulai Operasi. INFOJAMBI.COM. https://infojambi.com/bus-trans-siginjaimulai-operasi/

Suwarto, Nindya K. (2020). Karakteristik Kawasan Sekitar Halte BRT Trans Siginjai Jambi berdasarkan Aspek Tata Guna Lahan \& Aksesibilitas (Thesis). Universitas Gadjah Mada, Yogyakarta.

Queensland Government. (2010). Transit Oriented Development: Guide for Practitioners in Queensland. In Designing Sustainable Communities. the Department of Infrastructure and Planning, Queensland Government. https://doi.org/10.5040/9781474208444.ch-002

Transjakarta.co.id. (2016). Layanan Bus Transjakarta. Transjakarta Jak Lingko. http://transjakarta.co.id/produk-danlayanan/layanan-bus/transjakarta

Widyastuti, D. T. (2017). Konsep Pengembangan Kawasan Stasiun Kereta Api: Model Rail-Transit Oriented Development di Indonesia. In Universitas Gadjah Mada. Universitas Gadjah Mada. 